Geliș Tarihi: 04.02.2016

Kabul Tarihi: 01.04.2016
Mediterranean Journal of Humanities mjh.akdeniz.edu.tr VI/1 (2016) 63-72

\title{
Resmin Edebiyattaki Gölgesi Pentimento
}

\author{
Shadow of The Image in Literature Pentimento
}

Tülin ARSEVEN*

Öz: Edebiyat ile diğer sanat dalları arasında pek çok açıdan bir ilişki olduğu yadsınamaz gerçektir. Edebiyatımızda bazı topluluklar veya sanatçılar tarafindan zaman zaman bu durumun sorgulandığı görülmüştür. Garip Hareketi'nin edebiyat ile müzik ve resmin tedahülüne karşı çıkması ya da Ahmet Haşim'in şiirin sözden çok musikiye yakın olduğu anlayışını savunması bunun güzel örneklerindendir. $\mathrm{Bu}$ çalışmada da plastik sanatlardan resim ile fonetik sanatlardan edebiyat arasında kurulan bir çeşit bağ üzerinde durulmuştur. Resim sanatına ait bir terim olan pentimentonun edebî metinlerdeki yansıması irdelenmiştir. Bu kapsamda ilk olarak pentimento teriminin ne olduğu ilgili literatürden yola çıkılarak açıklanmışıı. Ardından anılarını yazdığı kitabına başlık olarak pentimento terimini vererek her iki sanat dalının da bu sözcüğü gündemine almasında rol oynayan Lillian Hellman ve eserinden kısaca söz edilmiştir. Bundan sonra ise pentimento teriminin Türk edebiyatında yüklendiği anlamlar tartışmaya açılmıştır. İlk olarak İnci Aral'ın Yeni Yalan Zamanlar romanında kurmacanın postmodern dokusu içinde önemli bir anahtar sözcük olarak pentimentonun kullanımı ele alınmıştır. Son olarak son dönem Türk şiirinde dikkat çeken iki önemli şairin şiirleri, Seyhan Erzöçelik'in Pentimento adlı şiir kitabı ile Orhan Alkaya'nın Yenilgiler Tarihi Cilt 1 başlıklı şiir kitabında yer alan Pentimento şiiri üzerinde durulmuştur. Konuyla ilgili olarak ulaşılabilen kaynakların taranıp dokümanların ve eserlerin analizinden elde edilen sonuç açıklanmıştır.

Anahtar sözcüler: Pentimento, Seyhan Erözçelik, Orhan Alkaya, İnci Aral, Lillian Hellman

Abstract: It is undeniable fact that in many respects there is a relationship between literature and the other branches of the arts. In our literature this situation is sometimes questioned by some communities or artists. Garip Ekol's opposition to the interpenetration of literature with music and art or Ahmet Haşim's idea that poem is closer to music than lyrics, are good examples of this. In this study, a kind of relationship between painting from the plastic arts and literature from the phonetic arts is emphasized. As an term art; pentimento's effects on literary works are scrutinized. In this context, firstly the meaning of pentimento is explained through the help of the relevant literature. Then, Lillian Hellman, who has had a large role in adding the term pentimento to both art and literary's agenda by giving this term as a title to her book including her memories, and her book is in part employed in this study. Then the term pentimento's loaded meanings in Turkish literature is opened for discussion. Firstly, the use of the term pentimento, which is an important keyword in the postmodern tissue of fiction in İnci Aral's novel " New Lie Times" (Yeni Yalan Zamanlar), is considered. Finally, two important poet's poems, which stirred interest in recent Turkish poetry, Seyhan Erözçelik's poem book Pentimento and Orhan Alkaya's Pentimento poem in the book entitled "Falls of History Volume I" (Yenilgiler Tarihi Cilt I), are emphasized. After scanning the sources that are accessed concerning this subject and analyzing the documents and works the results are given.

Keywords: Pentimento, Seyhan Erözçelik, Orhan Alkaya, İnci Aral, Lillian Hellman

\footnotetext{
* Prof. Dr., Akdeniz Üniversitesi, Eğitim Fakültesi, Türk Dili ve Edebiyatı Eğitimi Anabilim Dalı, Antalya. tarseven@akdeniz.edu.tr
} 
Pentimento, resim sanatına ait bir terimdir. Sanat Kavram ve Terimleri Sözlüğ̈̈’nde yağlıboya resimde yapılan hatayı saklamak veya fikir değiştirmek sonucu sürülen boya. Böylelikle istenmeyen kesim giderilerek resme devam etme olanağı kazanılır. Eski resimlerde örtücü boya katmanının zamanla saydamlaşması alttaki görüntüyü belirginleştirerek pentimentoyu ortaya çıkarabilir (Sözen-Tanyeli 2003, 188) şeklinde tanımlanmaktadır. Bu terimi ve edebiyattaki yans1malarını doğru değerlendirebilmek için önce ilgili literatüre göz gezdirmek gerekmektedir. Pentimento hakkında oldukça bir geniş bilgiye Charles Le Clair'in Color in Comtemporary Painting başlıklı çalışmasında rastlanmaktadır. Bu kitapta Le Clair, birkaç yıl önce Lillian Hellman'ın Pentimento adlı eserinin çok satanlar listesinin başında yer almasıyla birlikte bu sözcüğün merak konusu olduğunu belirtikten sonra Webster'da nasıl tanımlandığını ve bu terimin anlamını şu satırlarla anlatır:

“Webster'a göre bu sözcük, 'Değiştirilmiş veya boyanmış önceki resim, biçim veya firça darbesinin ortaya çıkması, varolması'dır. Bayan Hellman, şüphesiz, bu kelimeyi yarı unutulmuş anıların bir metaforu olarak kullanir. Bununla birlikte (ama yine de), bu bir resim terimidir, yaygin olarak kabul gören prensiplerden biri, yani bir resmin temellerinin bitmiş olan bir işin ayrılmaz bir parçası olduğudur.

Eski ustaların patronlarının ricasıyla resmi yeniden boyama-kıştan bahara ya da pagan tanrlardan Hristiyan azizlere değiştirme- alışkanlıklarının aksine modern sanatçllar resmi her firça darbesinin eşsiz katkısıyla oluşmuş organik bir süreç olarak görmekte. Ĕger burada amaç temiz bir görüntü ise, teknik tertemiz olmalı. Fakat daha kişisel çalışmalarda resmin yüzeyinin altındaki yaşam olumlu bir zenginliktir, ve biz sanatçının yaratım süreçlerindeki ilk dokunuşları, sonraki işaretleri, değişiklikleri ve silintileri görsel bir kayıt olarak algıları”" (Le Clair 1991, 216-217).

Le Clair'in açıklamaları bunlarla sınırlı değildir. Resim örnekleriyle desteklediği açıklamasında Le Clair, bir resmin daha sistemli bir biçimde kat kat (katmanlı) da yapılabileceğini; yüzey boyunca renk dizileri düzenlenebileceğini belirtir. Bunu geleneksel resim altı tekniğinin verniklenerek takip edilmesine benzetir. Ona göre burada iki kat yerine, dört veya beş kat çok farklı renklerde tıpkı vitray parçalarını yığmak gibi düzenlemenin sıkça yapılması söz konusudur. Bu noktada Le Clair, Rauschenberg'in çok katmanlı fotoğraf çekimlerinde bir çeşit üst üste bindirilmiş renkleri metal panele aktarmasını; Warhol'un aynı basit resim üzerinde konrast olan renk katmanlarını gösteren iki kanatlı bir tablo dizayn etmesini ve David Salle'ın farklı renklerde, farklı biçimlerdeki resimleri -gerçekçi bir manzara (mesela ince bir resim hattı ile kaplanmış olabilir)- birazcık soyut tasarım ve bir üst tabaka kolaj yaparak her biri temel uyumlu tabaka ile karakteristik renk tonunu üst üste yerleştirmesini örnek verir. Eksiksiz/tam bağlanım olduğunu bildiğini söylediği bu stratejinin Philadelphialı sanatçı Warren Rohrer'in çalışmalarında bulunabileceğini belirtir. Ona göre, Rohrer'in tuvalleri sadece ayrıntılı bir sistemin dışavurumun uygulaması değil aynı zamanda neredeyse gizli bir mistik anlam ile ilham verme durumudur. İște bu, pentimento kelimesinin önerdiği yüzeyin altındaki gizemli görüştür. Taban boyama ve katmanlama daha önce bilinen açık teknik terimlerdir, oysa pentimento antik, eskiden kalma, örtülü anlamlar ve bir tür psikolojik ve arkeolojik "kazı kazma" anlamına sahiptir. Le Clair, Bir Rohrer sergisinde, ilk izlenimlerden biri ve eserin içine doğru "kazıma işlemi”"nden sonraki kanı arasındaki karşıtlık şaşırtıcıdır, der. Ardından bazı tablolardaki renk katmanlarının birbiri üzerine nasıl atıldığını ayrıntılı biçimde aktarır (Le Clair 1991, 216-219). Le Clair'in yazısından bazı ressam- 
ların tablolarında çok katmanlı boyama tarzını bilerek yaptıkları anlaşılmaktadır. Ancak bir ressamın eserinde her zaman bile isteye bir pentimento yarattığını söylemek doğru olmayacaktır. Nitekim Şeref Bigalı'ya (1999) göre pentimento, bir anlamda özellikle suluboya ile resim yaparken ressamın karşı karşıya kaldığı bir risktir. Bu konudaki görüşlerini Bigalı şu sözlerle dile getirir:

"Çok renk tabakalariyla suluboya yapanlar da renklerini sadece palet üzerinde karıştırırlar; fakat bunlar resme önce açı tonları yerleştirmekle başlarlar. Ĕger, bu açık tonların daha da açık olması isteniyorsa, iki tabakanın birbirine karışmaması için resmin tamamen veya kısmen kurumasında sonra bu açık renkler daha da açılabilir. Böylece üç dört kat boya sürülebilir. Suluboyanın tipik -kendine has- şeffâflı̆̆ kayboldukça, riskler ortaya çıkar, tabakalar halindeki renkler daha mat bir görüntü alırlar.

Açık bir tonun, koyu bir tonu kapatmayacağı aşikârdır. Bazı suluboyacılar açık tonlardan başlamak gerekir diyorlar. Bu teknikte boyama esasinda yorumlama çok olur. Ve desen de tespit edilmiş değildir. Bu durumda düzeltmeler yapmak kolaylaşır; çalışma tarzı daha esnek ve daha zevklidir" (Bigalı 1999, 479).

Resim sanatında irdelenen bir başka konu ise resim-bilinç/bilinçaltı ilişkisidir. Kimi araştırmacılara göre resim yapma olayı, insan dimağından evvel tuval üzerinde cereyan etmektedir. Her firça vuruşu ile ressam kendini arama yolundadır. Bu arama bir iştir ve insanın oluşu ile ilgilidir. A. Gide'in 'sanat, hayatın yeter olmadığı yerde başlar' demesi, insani bir aranmaya işaret etmektedir. Bu aranma, insan eserlerinin oluşlarının bir tarihi yazılsa idi, daha açık görülebilirdi. Şu halde çağımız ressamı normal aranması içindedir. Ressam, boyayı tuvaline atmakta, bir orkestra yöneticisinin hareketlerine benzeyen atak, rahat-geniş, ihmalkâr, oynak hamlelerle ona firçanın strüktürünü vermektedir. Böylece boya, tuval üzerinde bazen karmakarışık, pıhtılaşmış, akmış bir meydan savaşı manzarasındadır. Yerine göre boya kazınarak, silinerek görülmemiş boya olaylarına gidilmektedir. Şeffaf sürtüşmelerle derinlik veren tonlara ulaşılmakta, boyaların karışımında kullanılan aracın strüktürel görünüşleri ilgi çekmekte ve ona değer verilmektedir. Organik bir oluşla birçok form doğmaktadır. Yeni boya unsurlarının eklenmesiyle tekrar doğmuş olan bazı formların kaybolmaları sonucunda, sanatçı kendi içine uyan bir boya ve form görünüşünde karar kılmakta ve tuvalini bitti düşüncesiyle bir yana bırakmaktadır. Bu onun bilinenin, var olanın ötesinde aranmasıdır. Bu tuval ile savaş, sanatçıyı çok yeni olanaklarla karşıladığı gibi, onu yalnız başına bir yolda gitmede de kuvvetlendirmektedir. Bu aranmalar sonunda ekseriyetle bilinmeyenlerle karşılaşabilinmektedir. Bu aranma, müzik kompozitörünün soyut dünyasından farksızdır. Sonuç olarak, eğer aranan insan, kendi ile mutlak olarak yalnız ise, katî şekilde kendi içine uygun bir form ve kişisel bir dünya görüşüne ulaşmaktadır (Turani 1964, 26-27).

Resim sanatını 1şığa kavuşan her şeyi büyük bir aşk ile incelemek ve bu aşkı renkler ve çizgiler aracılığı ile insanlara aşılamak sanatı olarak tanımlayan Bedri Rahmi Eyuboğlu (1986, 69), bu sanat dalını başka bir açıdan değerlendirmeye tabi tutar. Bedri Rahmi (1986), resmini yaptığı bir adamın aklından geçen düşünceleri merak ettiğini, aslında adamın başının resmini çizmek yerine bir şekilde başını yarıp, adamın aklından geçenleri tuvaline aktarmak istediğini söyler ve şu değerlendirmeyi yapar:

"Eşyanın görünen yanı dururken, onun içinde olup biteni düşünmek, resim sanatının olanaklarını aşmak demektir. Zaten bir ressam için 
doğadaki konu bolluğu ona hiçbir zaman eşyanın dışını bitirip içini merak etmeye vakit birakmamıştır.

Her nasılsa insan gövdesini ele alan ressam bu konu üzerinde dört-beş yüzyll oyalanacak kadar konu bulmuştur.

İnsan gövdesi ressamın elinde hallaç pamuğu gibi atılmış, fakat bütün bu didiklenmeye, sirf insan gövdesinin göze görünen yanı üstünde tam bir fikir edinebilmek için başvurulmuştur. Ve gerçekten insan gövdesini en küçük ayrıntılarına kadar incelemek tutkusu bir aralık ressamı göze görünenden çok görünmeyene saplamış ve birçok ressam işi allâmeliğe dökerek, canım insan gövdesini bir kemik veya kas torbasina çevirmişlerdir" (Eyuboğlu 1986, 70).

Bedri Rahmi Eyuboğlu'nun yukarıdaki sözlerinden hareketle pentimentonun da aslında insanı, bir tuvalin yüzeyinde görünen kompozisyonunu aşıp, gizli kalmış hatalı çizimlere ya da ressamın modellemedeki tercihlerine götüren bir teknik olduğunu söylemek yanlış olmasa gerektir. Poetika noktasında görüneni anlatmanın yanı sıra görünenin arkasında saklı kalan görünmeyenin peşine düşen şair ve yazar sayısı da az değildir. Nitekim Jale Parla'ya göre, "Jakobson ve Shklovsky'ye göre tüm edebi sanatlar, örneğin imgeler, eğretilemeler, ritm, ses, kafiye vb. tek bir amaca, siradanlık ve tekdüzelikten kurtulma amacına yönelik yapılır. Bu yabancllaştırmanın iki işlevi vardır: Bir tanesi, gündelik yaşamda yitip giden duyumsamaların sanat yoluyla yeniden kazanımını sağlamak, ikincisi sanat geleneğinin sürekli yenilenmesine hizmet etmek. Belli bir sanat türü ya da anlatı biçimi zaman içinde yorulur, tekdüzeleşir, heyecan verici olmaktan çıkar. O zaman bu biçim, yabancılaştırma yöntemiyle yenilenir. Yeni ve çarpıcı deyişler icat edilir, anlatı parodiye yaslanarak sanatsal tekniklerini vurgular, kısaca, sanatsallığını 'öne çıkarmak' için akla gelebilecek her yola başvurur" (Parla 2009, 46).

Edebî metnin incelenmesinde sanatçı, okur, inceleme yöntemi ile bunlara bağlı olarak yorumlama ve okuma dikkate alınması gereken unsurlardır. Tzvetan Todorov bir metnin incelemesinden söz ederken okuma, metnin mekânı içindeki bir güzergâhtır, der. Todorov'a göre bu güzergâh, harflerin soldan sağa ve yukarıdan aşağıya birbirine eklemlenişiyle (biricik olan tek güzergâh budur, bu nedenle metnin tek bir anlamı yoktur) sınırlı değildir. Aksine, bitişik olanları birbirinden ayırır, uzak olanları bir araya getirir, metni çizgisellik olarak değil mekân olarak yeniden kurar. Bütünün ve parçaların aynı anda birlikte var olduklarını kabul eden ve böylece mutlak bir başlangıç olasılığını ortadan kaldıran meşhur 'hermenötik çember' de, zaten birden fazla yorum olması gerekliliğine işaret ediyordur. Ancak bütün 'çemberler' birbiriyle eşdeğer değildir: Çemberler, metinsel mekânın az ya da çok sayıda noktasından geçmemizi sağlar, bizi metnin az ya da çok sayıda öğesini bir kenara bırakmaya zorlarlar. Herkesin pratikte bildiği gibi, hiçbiri tamamen sadık olmasa da, diğerlerine göre daha sadık olan okumalar vardır. Yorumlama ve betimleme (anlamın betimlenmesi) arasındaki fark bu iki edimin doğasından kaynaklanmaz, bir derece farkıdır yalnızca; ancak, böyle de olsa, didaktik bir bakış açısı çerçevesinde bu farkı gözetmek yararlı olacaktır (Todorov 2001, 35-36). Bir metinde yorumlama ve betimleme arasındaki fark önemlidir. Bu kapsamda Le Clair'in resim tekniklerini konu edindiği Color in Contemporary Painting başlıklı çalışmasının "Pentimento" alt başlığında Lillian Hellman'dan ve onun Pentimento (1993) adlı anı türündeki kitabından söz etmesi de anlamlıdır. Hellman, aslında söz konusu kitabında bilinç akışı tekniğinden yararlanarak anılarını, uzun yıllar sonra kimi zaman net olmayan kimi zaman bilincinin ve bilinçaltının onu yanıltabileceği varsayımının altını çizerek anlatır. Hellman'ın Pentimento adlı kitabını Türkçeye çeviren Filiz Ofluoğlu, kitabın önsözünde yaptığı değerlendirmede Hellman'ın yapıtlarında ölçülü 
bir sanat kavramı olduğunu öne sürer. Ofluoğlu'na göre Hellman'ın diyalogları kusursuzdur, kişiler kesinlikle belirgindir, insanların davranışı, ilişkileri ve dürtülerinde büyük bir sezi gizlidir. Hellman'ın Pentimento'da anıların "anımsamıyorum" ya da "bilmem anlayabilmiş miydim" gibi ifadelerle aktarması ile bir anlamda Faulkner türü bir teknik kullandığını; bunun ise söylenenin ardındaki kavramı okura aktarmakta etkili bir yol olduğunu belirtir. Ofluoğlu'na göre Hellman'ın anlattığı kişilere yakınlığı, sevgisi, anlatım biçiminin içinde gizlidir. Değişik yerler, değişik kişiler, değişik zamanlar arasındaki bağ, bu yakın ve güçlü ilişkiyle yansıtılır. Cesur bir kitap olarak nitelediği Pentimento için Ofluoğlu, "Dramatik niteliği, yalnızca anlattı̆̆ l kişilerin yaşamını çevreleyen toplumsal kargaşa ve gelişimden değil, daha çok zamanlama yeteneğinden ve dengeli gücünden doğar. Kesin ve yer yer eğlendiren, neşelendiren ayrıntılar, ve tam yakıştırmalı sözcükler sayesinde, anı anlatımı da, kendi yaşamı gibi, enerji doludur, canlıdır ve dürüsttür” değerlendirmesini yapar (Hellman 1993, 7-8).

Hellman (1993) da kendisi hakkında yapılan değerlendirmeleri haksız çıkartmayacak biçimde anılarında dünü ve içinde yaşanılan günü iç içe anlatır ve bu duruma dair duygularını " $O$ günlere dair bir ylğın karmakarışık anım vardır: Öğrenilip unutulan şeyler ya da yarı anımsananlar, bunlar unutmaktan da beterdir" (Hellman 1993, 207) sözleriyle dile getirir. Hellman, öğrenilip unutulan ya da yarı anımsananların kişide unutmaktan beter bir durum oluşturduğunu belirtirken bellekteki üst üste geçmiş görüntülerin yarattığı sıkıntıların da altını çizmiş olur. Bu noktada pentimento sözcügünün Faulkner tarzı anlatımla biçimlenmiş anı türündeki metinler için bir metafor olarak kullanılabileceğini söylemek yanlış olmaz. Ancak aslında pentimentoyu edebî metinde özellikle de kurmacada kullanmaya en uygun yap1, postmodern anlatılarda görülmektedir denilebilir. Bunda postmodern anlatının anlatım tekniklerinin etkisi büyüktür. Çünkü araştırmacıların da belirttiği gibi postmodern anlatılarda nedensellik yoktur, her şey boşluktadır, boyutsuzdur, ele avuca gelmez, cisimleşmez. Gerçek ve düş ayırt edilemez, dil bir yanılsama aracı olarak kullanılır, masalsı, karmaşık bir hâle sokularak 'giz' duygusu sürekli beslenir (Tosun 2011, 77). Postmodern metnin doğası da postmodernizmin en az kendisi kadar karmaşık, paradoksal ve hatta belli bir kalıba sığmayacak kadar tanımsızdır (Emre 2004, 101). Edebî metinde pentimento, metinlerarasılık ile de ilişkilendirilebilir. Yıldız Ecevit $(2009,110)$, "Yeni edebiyat terimleri dizgesinde metinlerarasılık (intertextuality) diye adlandırllan olgu, üstkurmacanın bir türevidir; üstkurmaca yazarının metinde oluşturmayı amaçladiğı kurmaca doğanın önemli bir parçasıdır" diyerek yazarın öykü içinde öyküler anlattığını böylece edebiyatın dış dünyayı/yaşamı anlatmaktan çok, kendine dönme eğilimi gösterdiğini öne sürmektedir. Ecevit'e göre çok katmanlı açık yapıtların ana özelliği, çok sayıda anlamı içinde barındıran metaforik dokular oluşudur. Çağcıl estetiğin ana biçim öğelerinden biri ise, bu çokkatmanlı/çözümsüz dokuların yapı taşı olan imgedir. İmgenin birçok dildeki karşılığı, resimle/çizgiyle/görüntüyle bütünleşen bir anlam içerir. Dış dünyadan alınma resimlerle oluşur imge (Ecevit 2009, 195). Bir edebî eserde çok katmanlı metaforik dokuların bulunması, burada bir pentimentonun varlığından söz etmek için yeterli değildir. Ancak kurmaca yapısı nedeniyle postmodern anlatının pentimento için uygun bir zemin oluşturduğu söylenebilir. Metinde olayların/duyguların/imgelerin altının kazınması sonucu anlatının okura görünenin arkasındakini, görünmeyeni sunması durumunda pentimentodan söz edilebilir. Bu noktada çok katmanlı anlatı yapısına sahip olmasının yanı sıra pentimento sözcügünün kurguda önemli bir görev üstlenmesi nedeniyle İnci Aral'ın Yeni Yalan Zamanlar (1995) adlı eseri üzerinde durmaya değer niteliktedir. İnci Enginün, son yıllarda postmodern romanın en iyi örneklerini veren bir yazar olarak tanımladığı İnci Aral'ın Yeni Yalan Zamanlar'ını da son yılların en ilginç romanlarından sayar. Enginün'ün...

"Yazarın bir çeşit bulmaca çözmeği hedeflercesine düzenlediği bölümler, 
kitabinin adınin değişik okumalara uygun düzeni (ben bu okumayı 16 ya kadar çıkardım) ve kapak resmi de dahil, eserin bütün unsurlarının kullanılmasıyla değişik okumalara, yorumlara imkân vermektedir. 'Pentimento' kelimesi bu roman-bulmacanın anahtar kelimesidir. Yağlıboya bir resimde ressamın üstünü boyayla örterek yok ettiği bölüm ya da ayrıntının sonraki yıllarda yeniden belirmesine verilen ad olan 'pentimento' eserin ana fikridir. Yazar bunu özellikle kadının kaderine uygulamıştır. Romancı ă̆ırlıklı olarak kadının öteden beri devam eden toplum içindeki yerini araştırır ve kadının kaderine mahkûm olduğuna inanmakla birlikte bu macerada kadının yalnız olmadığını, hangi cins, hangi meslekte olursa olsun ferdin bizzat veya en yakınları vasitastyla oluşturduğu hapishaneleri işaret eder" (Engünün 2003, 363-364).

sözleriyle değerlendirdiği bu roman, bir yandan pentimento terimini tanıtırken, diğer yandan pentimentoyu bir teknik olarak kurmacada uygulamaya çalışır. Bunu yaparken de Aral, Yeni Yalan Zamanları'n kurmaca dünyası içinde ilk olarak bir resimden söz eder. Romanda bu bölüm şöyle yer alır:

“Görür görmez çarpıldiğııın farkındayım' dedi Metin. 'Bende de aynı etkiyi yaptı gördügüumde. İyi bir resim. Ressamı tanınmış biri değil ya da belli değil. Birkaç ay önce antikacı bir arkadaşımdan aldım. Pek kolay olmadı tabii, satmak istemiyordu, değerinin çok üstünde bir bedel ödemek zorunda kaldım'.

'Ama bu yüz,' dedim, 'Çok tanıdık geliyor bana. Daha önce gördüğüm birini anımsatiyor sanki'.

'Her görende aynı etkiyi bırakayor' dedi Metin. 'Güzelliği de burda bence.

Resimde tarih bile yok. Değeri sıfir, ama öylesine naif ki çok sevdim. Biraz eski bir portre üstü boyayla büsbütün kapatılmadan amatör işi yeniden boyanmış, elden geçirilmiş. Yani eski resim üstünde oynanmış. Gel bak...'

Kalkıp resme yaklaştık.

Görüyor musun? Hem eski hem taze boya var tuvalde' dedi Metin. 'Eski boya tabakasl yer yer saydamlaşıp çatlamış. Klasik bir 5 portrenin üzerine daha çağdaş bir yorumla ve alttaki lekelerden yararlanılarak yapılmış bir çalışma bu. Yeni boyanin ince sürüldüğ̈̈ yerlerden de alttaki çizgi ve renkler görünüyor. Bir tür pentimento yani'.

'Bence resim asıl bu ikinci boyamada can kazanmış' dedim. 'Belki de bu eşsiz gizemi yaratan eskiyle yeninin bu biçimde kaynaştırllip dördüncü bir boyut oluşturulmasıdır. Gene de kesinlikle biri olmalı bu kadın. Çünkü bu yüzde inanılması gü̧̧ bir gerçeklik var, neredeyse elle tutulur bir ruh!'” (Aral 1995, 53-54).

Böylece romanda ilk olarak hem bir tablo hem de bu tablo üzerinden pentimento terimi ayrıntılı biçimde anlatılmış olur. Romanın henüz başlarında bu tablo nedir ve resimdeki kadın kimdir soruları ara düğüm halinde okurun karşısına çıkar. Kurguda zaman zaman bu tablo yeniden gündeme gelir. Romanın 'Melike Eda' başlıklı son bölümünde resimdeki kadının ve Eda'nın kim olduğu açıklanır. Çok önce yapılmış bu resmin üstünde yeniden boyamalar yapıldığı bilgisi de verilir. Yeni Yalan Zamanlar'ın kurgusu içinde küçük bir ayrıntı ve resim sanatına ilişkin bir 
küçük bilgi aktarımı gibi duran pentimentoya dair satırlar aslında tüm roman için İnci Enginün'ün de belirttiği gibi anahtar görevi görmektedir. Romanda bir resmin üzerine yeniden boya sürülerek alttaki görüntünün değiştirilmiş olduğundan ve zaman içinde üst tabakadaki boyanın incelip alttaki eski görüntünün yeniden yüzeye çıktığından söz edilir. Tabloda oluşan bu durum ile aslında insanlar arasındaki ilişkilere gönderme yapılır. İnsanların dış dünyaya görünen yüzleri ile içlerinin farklılığına, gerçek sanılan görüntülerin aslında zahiri olabileceğine bir atıfta bulunulur. Özellikle her bir roman kişisinin birbirinden farklı kimliklerle defalarca yeniden ve yeniden ancak hangisinin doğru olduğu (ya da yalan olduğu) belli olmayan bir biçimde görünmesi pentimentonun romanda hayat bulmuş halidir. İnci Aral'ın romanındaki resim ve resimde bir çeşit deformasyonu imleyen pentimento sözcüğü, aslında postmodern anlatının önemli özelliklerinden biri olan yapıbozuculuğu işaret etmektedir.

Pentimento sözcügü ve bu sözcüğün anlamının yarattığı metafordan esinlenen anlatım tekniklerini edebiyatın diğer türlerinde de görmek mümkündür. Türk edebiyatında bunun güzel bir örneği olarak Seyhan Erözçelik'in şiir kitabı Pentimento (2011) verilebilir. İki ana bölümden oluşan bu kitabın ilk bölümü Pentimento başlığını taşımaktadır ancak aynı başlıkta bir şiir bulunmamaktadır. Kitabın ilk bölümünde Maarif Koleji, Askeri Lojmanlar, Köhne’de, Aşk mı Taş $m \imath$ ?, Bir Madolindin Sen gibi 56, Palimpsest başlıklı ikinci bölümünde ise Bir Leon Hikayesi, Yangınım Ben Sana ve Kubbe başlıklı üç şiir yer almaktadır. Pentimento adlı bölümde yer alan şiirlere bakıldığında şairin, anılarına yöneldiği; bunları aktarırken bilinçle bilinçaltını, düşle gerçeği harmanlayarak verdiği görülmektedir. Bu bölümdeki şiirlerin yazımında da özellikle parantez içi anlatımlar ve yer yer italik dizilmiş sözcükler veya dizeler kullanılarak resim sanatındaki pentimentonun şiir düzlemine aktarılmaya çalışıldığı görülür. Böylece ilk olarak şiirin biçiminde farklı iki düzlem oluşturulmaya çalışılır. İkinci olarak ise duyguların dile getirilme "an" ile geçmişin izleri ve anılar bir arada verilerek içerikte de iki ayrı düzlem oluşturulur. Bu ise bir tablodaki boya altı görüntülerinin yüzeye vurması yani pentimentonun şiirdeki görünümünü oluşturur. Hellman'ın anılarında görülen Faulknerci yaklaşımın bir başka örneği anlatıda kendini gösterir. Örneğin kitabın ve ilk bölümün ilk şiiri olan Maarif Koleji şöyledir:

Annenler, yazlikta.

Biz, yaz tatilindeyiz.

Senin odanda. (Nedense, salonda değiliz. Ortalığı dağıtmayalım, di mi!)

Senin odanda, senin yatağında.

Ağustosa karşı perdeleri örtmüşüz.

On beşi, yeni devirmişiz.

Di mi?

Leonard'1 seviyoruz, dinliyoruz, deliler gibi.

Şarap içiyoruz.

Suçlular gibi.

Di mi?

\{Suç ne ki?

Sen ağllyorsun. Neye ăgllyorsun? 


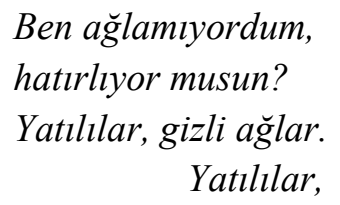

hatırlamaz.

Galiba,

biz,

hatırlartz.

Biz,

A ğlarız.

Di mi!\}

On beşi yeni devirmişiz.

Öpüşüyoruz, devriliyoruz.

Geçmişe de,

Perdeleri örttük şimdi.

$$
\text { Di mi? (Erözçelik 2011, 3-4). }
$$

Şair, ilk gençliğine dair bir anıyı dile getirirken, bir yandan da hem o gün dile getirilmemiş, gizlenmiş duygularını hem de geçmişe döndügünde hissettiklerini ayraç içinde ya da italik dizerek vermiştir. Böylece üzerinde oynamalar yapılmış, boyanıp hatalı çizimler düzeltilmiş bir tablo gibi bilincin katmanları su yüzüne çıkarılmıştır. Maarif Koleji’nde görülen yapı özellikleri Seyhan Erözçelik'in kitabının Pentimento adlı bölümünde yer alan diğer şiirlerinde de görülür. İndepen başlıklı şiirin bir bölümü ise şöyledir:

$$
\text { (...) }
$$

Mama!

\section{Mama?}

\section{Anne?}

$$
\begin{aligned}
& \text { Alo... Anne- } \\
& \text { Bu dil de böyle işte... } \\
& \text { Güvercin kanadı gibi (Erözçelik 2011, 66). }
\end{aligned}
$$

Son dizedeki italik dizilmiş olan "Güvercin ka" kısmı, Cemal Süreya'nın Üvercinka başlıklı şiirini hatırlatmaktadır. Bu kitapta şiirleri doğru okumanın, anlamanın yolu, pentimento terimini bilmekten geçmektedir. Resim sanatındaki çok katmanlı yapı ve tabakalar, şiirin narin ve küçük alanında olabildiğince başarılı bir biçimde yansıtılmıştır. Seyhan Erözçelik'in Pentimento adlı kitabının sözlük anlamı yeniden yazılmış parşömen kâğıdı olan Palimsest isimli ikinci kısmı da hayli ilginçtir. Şiir, öykü ve anı türlerinin iç içe geçtiği bu bölümdeki anlatılar da başlı başına bir inceleme konusudur. Tıpkı İnci Aral'ın Yeni Yalan Zamanlar adlı romanının anahtar sözcüğünün pentimento olması gibi Seyhan Erözçelik'in şiirinin de açımlayıcısı pentimento terimidir. $\mathrm{Bu}$ terimi başlık edinmiş bir başka metin de Orhan Alkaya'nın Yenilgiler Tarihi Cilt 1 (2011) adlı kitabının son şiiridir. Hayli uzun olan ve birbirinden farklı dize sayısındaki parçaların bir araya gelmesiyle ve her bir parçanın "(işte) böyle bir şeydi yaşadıklarımız" redifiyle oluşturulan bu nahif şiir, Seyhan Erözçelik’in şiirinden yapıca farklıdır. 
"işte, durdurulmuş ve buruşturulmuş bir şey bu yaşadıklarımız! Güneş bulutların arasından slyrilır gibi - - iliklere işleyen yağmur altında gibi - işte, gibi bir şey bu unutulan ne varsa, hayatımı"” (Alkaya 2011, 79).

dizeleriyle başlayan şiir yine,

"işte, durdurulmuş ve buruşturulmuş bir şey bu Yaşadıklarımız” (Alkaya 2011, 89).

dizeleriyle biter. Aynı olan başlangıç ve bitiş dizelerinin arasında 'durdurulmuş ve buruşturulmuş' olma halini tamamlayan, büyük bir hayat muhasebesi yapılır. Böylece, aslında pentimento anahtar sözcüğü bu şiirde, olaylar yaşanılırken söylenemeyenlerin sonradan dile getirilmesi şeklinde belirir.

İnternetteki sanat ve şiir sayfalarında içinde pentimento sözcüğünün yer aldığı bir şiire daha rastlanmıştır. Bu da Düşerken Koştuğum Yerler başlıklı bir kitabı olan Nazende Kaya'nın bir internet sitesinde (bk. http://www.antoloji.com/pentimento-poseidon-siiri/) Pemtimento Poseidon adlı şiiridir. Aşağıya küçük bir bölümü alınan bu şiirde pentimento sadece sessel bir unsur olarak görünmektedir:

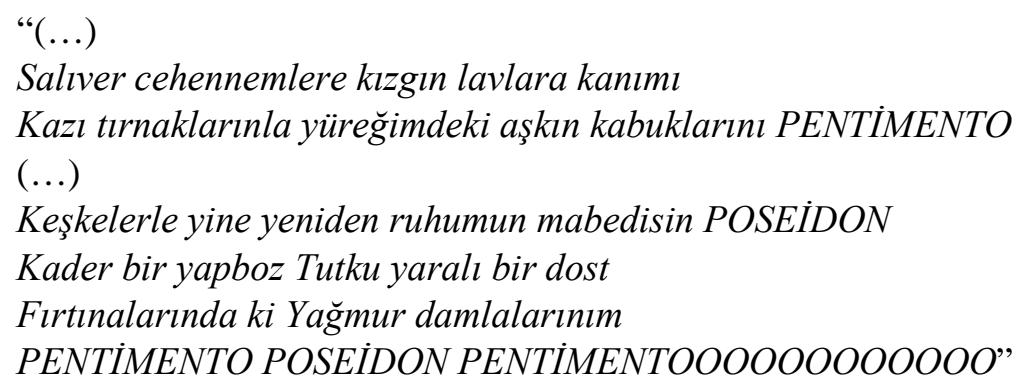

Sonuç olarak, bugün edebiyatımızda roman ve şiir türlerinde az sayıdaki eserde karşımıza çıkan pentimento terimi, genellikle buruk anıların ya da pişmanlıkların metaforik ifadesi şeklinde kendini göstermektedir. Daha çok, bilinç kazındıkça altından çıkan yaralayıcı, incitici ve pişmanlık verici yaşanmışlıkların gölgesi ya da hatırlanması anlamında kullanılmaktadır. Yeni Yalan Zamanlar'da bir kadının tuvale yansıyan yüzünden ve onun üzerine yapılan yeni resimden birey olarak kadının içinde bulunduğu kuşatılmışlığı, yeni bir resmin altına saklanarak kırma çabasını imler. Seyhan Erözçelik'in şiir dilinde ise bilinç ile bilinçaltının uyumlu bir akış içinde verilmesinde bir tablodaki çift düzlemin metnin dokusu içinde yansıması hayli başarılıdır. Orhan Alkaya'nın şiiri ise bütünsel anlamda bir yaşantının muhasebesini yaparken, ara ara görünen, belli belirsiz ancak bu silik görüntüsüne karşın can yakan duyguların güçlü anlatımıdır. Pentimento sözcüğünün özellikle kullanılmış olduğu bu üç edebî metin de hayli başarılıdır. Üçü arasında pentimento sözcüğü ve bu terimin resim sanatında ifade ettiği anlam dışında bir ortaklık ya da benzerlikten söz etmek mümkün değildir. Pentimento'nun gelecekte daha sık kullanılması ve belki de bir anlatım tekniğine, hatta bir edebî terime dönüşmüş olarak görülmesi ihtimal dâhilindedir. Ancak şimdilik sanat disiplinleri arasındaki bir çeşit etkilenmenin bir sonucu olarak, türü ne olursa olsun bir edebî eserde en az iki katmanlı bir yapının dokuları arasındaki bilinç akışını simgeleyerek edebiyattaki varlı̆̆ını duyurmuş görünmektedir. 


\section{KAYNAKÇA}

Alkaya O. (2011). Yenilgiler Tarihi. (1. Cilt). İstanbul 2011. Aral İ. (1995). Yeni Yalan Zamanlar. İstanbul 1995.

Bigalı Ş. (1999). Resim Sanatı. Ankara 1999.

Ecevit Y. (2009). Türk Romanında Postmodernist Açılımlar. İstanbul 2009.

Emre İ. (2004). Postmodernizm ve Edebiyat. Ankara 2004.

Enginün İ. (2003). Cumhuriyet Dönemi Türk Edebiyatı. İstanbul 2003.

Erözçelik S. (2011). Pentimento. İstanbul 2011.

Eyuboğlu B. R. (1986). Resme Başlarken. İstanbul 1986.

Hellman L. (1993). Pentimento. Çev. F. Ofluoğlu. İstanbul 1993.

Le Clair C. (1991). Color in Contemporary Painting. New York 1991.

Parla J. (2009). Don Kişot'tan Bugüne Roman. İstanbul 2009.

Sözen M. \& Tanyeli U. (2003). Sanat Kavram ve Terimleri Sözlüğ̈̈. İstanbul 2003.

Todorov T. (2001). Poetikaya Giriş. İstanbul 2001.

Tosun N. (2011). Modern Öykü Kuramı. Ankara 2011.

Turani A. (1964). Resim Üzerine. Ankara 1964. 